\title{
Anglo American framework for strategic dewatering plans
}

\author{
C Cintolesi Anglo American, Chile \\ G Beale Piteau Associates UK Ltd, UK \\ J Dowling Piteau Associates, USA \\ J Kotze Anglo American South Africa Ltd, South Africa
}

A Rowland Piteau Associates South Africa, South Africa

S Mansell Piteau Associates Chile Spa, Chile

\begin{abstract}
The increasing size and depth of open pits and underground workings, and the increasing regulatory constraints imposed on mining operations, mean that planning and implementation of the dewatering strategy must now form an integral part of the mining cycle. Anglo American, in conjunction with Piteau Associates, has developed a standardised strategic approach for use across its global mine sites. The dewatering program must incorporate both planning and operations, including (i) the required regulatory approval in a timely manner, avoiding over-commitments, (ii) dewatering ahead of mine operations, (iii) avoidance of non-delivery of ore and/or higher mining costs, (iv) achievement of pore pressure targets to meet slope design acceptance criteria, and $(\mathrm{v})$ incorporation of the pit water into the site-wide water balance and management of risks. This paper describes the six identified key steps for strategic planning and implementation providing examples. It is consistent with the Large Open Pit (LOP) project guidelines (Beale \& Read 2013).
\end{abstract}

Keywords: dewatering, depressurisation, pit slope water management

\section{Introduction}

This document provides a summary of the consistent (standardised) approach for developing strategic dewatering plans at Anglo American mine sites (Anglo American \& Piteau Associates 2018). Currently, several open pits and underground operations of multiple commodities have dewatering requirements and challenges. Sites involve mixed permeability systems, and variable geological and hydrological settings. Dewatering and slope depressurisation requirements, risks and costs are increasing, including interference with in-pit mining activities and targets, as pits get deeper and faster deepening rates below pre-mining groundwater level occur. Challenging 'ore and water' mines going forward are becoming more common. There is a need to develop strategies and plans to ensure suitable dewatering systems are included in the different stages of project studies, and regular mine plans update cycles during operation and closure stages, to enable successful implementation on time.

The mine dewatering program must incorporate planning for both groundwater and surface water impacts on the mining operation. Benefits for the mine include:

- Impacts assessment and mine water management permitting in a timely manner; avoiding over-commitments and permit conditions that result from academic model artefacts.

- Avoidance of higher mining costs related to slower mining, haulage costs (wet ore), equipment wear, tyre wear, wet drill and blast, poor grade control and reactive dewatering.

- Achievement of defined pore pressure targets to meet slope stability design acceptance criteria. 
- Incorporation of the pit water into the site-wide water balance and management of risks associated with offsite discharge of mine water.

Development of a dewatering strategy will normally include six steps (Figure 1 ) as follows. Steps 1 to 4 apply for study and operational stages, and steps 5 to 6 are solely operational. Steps can be applied at more advanced study stages and mine plan updates to incorporate new information and regular update of the dewatering strategy.

Step 1: Screening-level assessment.

- Assessment of the required scale of the program.

- Planning of the required resources.

Step 2: Characterisation of the geological and hydrological conditions.

- District scale.

- Site scale.

Step 3: Development of a conceptual model and strategic planning.

- Development of the overall water management strategy, including dewatering options and trade-off analysis.

- Preparation of the Terms of Reference (ToR) and budgets for the 5 Year Plans (5YP) and Life of Asset (LoA) planning cycles.

Step 4: Mine dewatering system design.

- Analytical and/or numerical supporting analysis.

- Assessment of risks.

Step 5: Implementation.

- Progressive installation of the system based on the mine plan.

- Interactive adjustment based on the ongoing monitoring results.

- Definition of staff, roles and organisational structure.

Step 6: Monitoring and reporting.

- Feedback loop to optimise the implementation.

- Strategy and implementation review by stakeholders and experts.

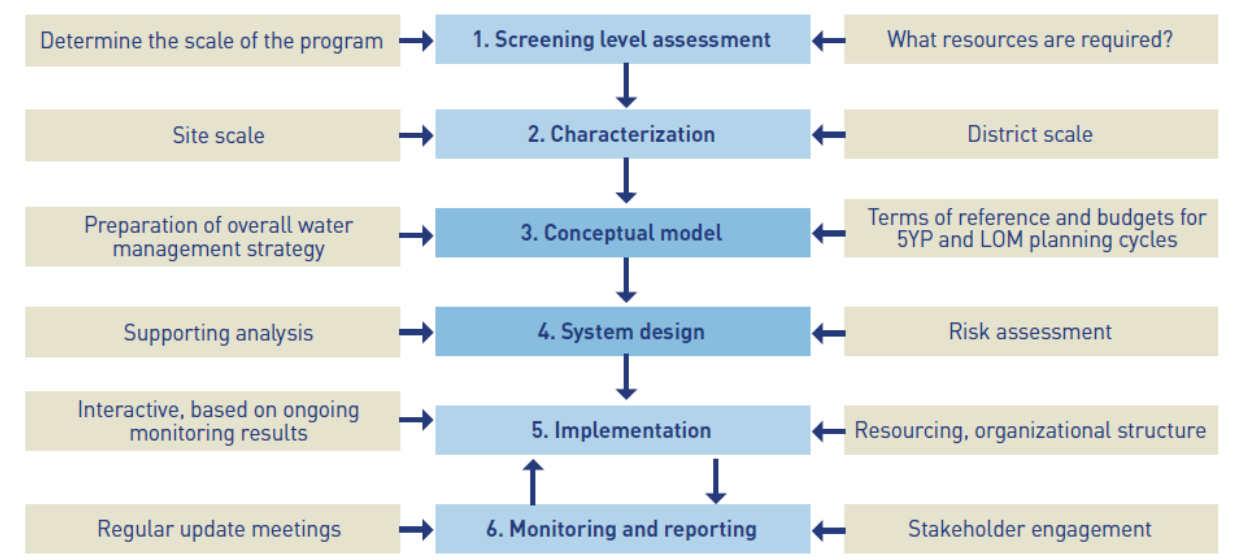

Figure 1 Steps for preparing and implementing the strategic dewatering plan

The following sections provide further details for each of the six steps. 


\section{Step 1: Screening-level assessment}

It is first necessary to prepare a screening-level assessment. The overall objective is to determine the required scale of the mine dewatering program. The key goals are:

- To provide an early assessment of the likely issues for water control.

- To determine the level of staffing, contractors and resources that may be needed to characterise the site and develop the dewatering plan.

The screening-level analysis is carried out based on existing information for the site (climate, topographic setting, geology) together with early mine planning information and the available hydrogeology data for the site and/or the district (often obtained by 'piggy-backing' on the geology drilling program). Benchmarking with operations in other similar settings is an important part of the screening-level process.

The deliverable of the screening-level assessment is an order-of-magnitude estimate of the mine dewatering requirements for the site. The key gaps are identified, a detailed characterisation program is prepared and required staffing and resources are defined.

\section{Step 2: Characterisation of hydrogeological conditions}

\subsection{Actions required}

The characterisation program will usually need to include conditions at a district scale and at a mine scale. The actions will typically include:

- Collection of data from the resource and mineral characterisation (geology) program.

- Drilling of dedicated hydrogeology drillholes and piezometers.

- Combining the hydrogeology and geotechnical characterisation drilling.

- Implementation of field trials, pilot programs or cross-hole testing.

\subsection{Data from the geology and condemnation drilling programs}

Key information for early-stage planning is whether groundwater elevations are similar and interconnected (indicating continuity of flow) or discontinuous (indicating the presence of hydrogeological boundaries). Correlation of groundwater levels to observed geology is an important early step. The geology drilling program is usually focussed on the mine area itself (area of the orebody). Information on the district hydrogeology can often be obtained from the condemnation (sterilisation) drilling programs for other site facilities. Relevant geology drillholes that can improve hydrogeological characterisation should have piezometers installed.

\subsection{Additional hydrogeological investigations}

Once the basic geology and hydrogeology is understood, a program of focussed hydrogeology drilling can be carried out, as required. The goal of additional dedicated hydrogeology drilling is to further characterise the hydrogeological units that may be important for dewatering or for controlling local pit slope pore pressures.

It is usually beneficial to combine the hydrogeology and geotechnical drilling programs. Investigation methods include:

- Packer testing of low permeability ('weak') geotechnical units.

- Prolonged injection or airlift testing of diamond drillholes.

- Correlation of hydrogeological observations with core or televiewer logs.

- Installation of multi-level grouted vibrating wire piezometers strings. 
- Bundled installation of vibrating wire piezometers, in the same holes as time-domain reflectometers (TDRs), inclinometers, or accelerometers.

Stakeholder interaction is required with the geotechnical, geology, mine planning, water management and environmental groups to optimise hydrogeological characterisation, including suitable contractor engagement, integration of multi-purpose drilling campaign with different disciplines, drillhole locations, water balance, and environmental monitoring programs.

\subsection{Field trials}

Depending on the site-specific characterisation and dewatering/depressurisation needs, hydrogeological investigation should include some form of large-scale (cross-hole) testing to allow the groundwater response to hydraulic stresses to be observed in piezometers. This may take the form of:

- Conventional pumping trials in higher permeability ('pumpable') units.

- Pumping or injection using packers in medium to high permeability formations.

- Hydraulic responses to pumping, airlift or injection using widely spaced holes in permeable formations.

- Hydraulic responses to airlift or injection using closely spaced holes in low permeability units. Obtaining responses in piezometers to airlift of injection in nearby holes provides confidence that formations can be depressurised.

\section{$4 \quad$ Step 3: Conceptual model and strategy development}

\subsection{Key components of the conceptual model}

The most important step in any mine hydrogeological program is the development of the conceptual model and should incorporate the district scale and the mine scale. A conceptual hydrogeological model may be described as a realistic, defensible, albeit simplified, representation of the hydrogeological system. The hydrogeological system can be broken down into eight fundamental components, as follows:

Geology:

- The district-scale geology and rock mass.

- The ore deposit geology.

- The major structures including adverse orientations for slope stability.

Hydrology:

- Natural recharge to the groundwater system.

- Artificial recharge to the groundwater system.

- Discharge from the groundwater system.

Hydraulic properties and water quality:

- The hydraulic properties and water quality of the main geological units.

- The groundwater flow paths.

Figure 2 presents an example of a conceptual hydrogeological section at Los Bronces copper mine, a large open pit and a nearby underground development of Los Sulfatos copper deposit, located below the Yerba Loca protected area, currently in permitting process. The hydrogeological characterisation campaign included a successful upward (up to $600 \mathrm{~m}$ ) and downwards drilling and testing campaign executed from Los Sulfatos exploration tunnel. Multiple core boreholes, packer testing, installation of grouted vibrating wire 
piezometers and water sampling were conducted (Anglo American 2019). Integration of multiple hydraulic testing for open pit dewatering investigations with recent underground campaign are presented in Figure 3. Grouped with hydrogeological units, Los Bronces and Yerba Loca area results indicate very low hydraulic conductivity at the Los Sulfatos area and very low to moderate hydraulic conductivity at the Los Bronces open pit; relevant dewatering needs solely at Los Bronces.

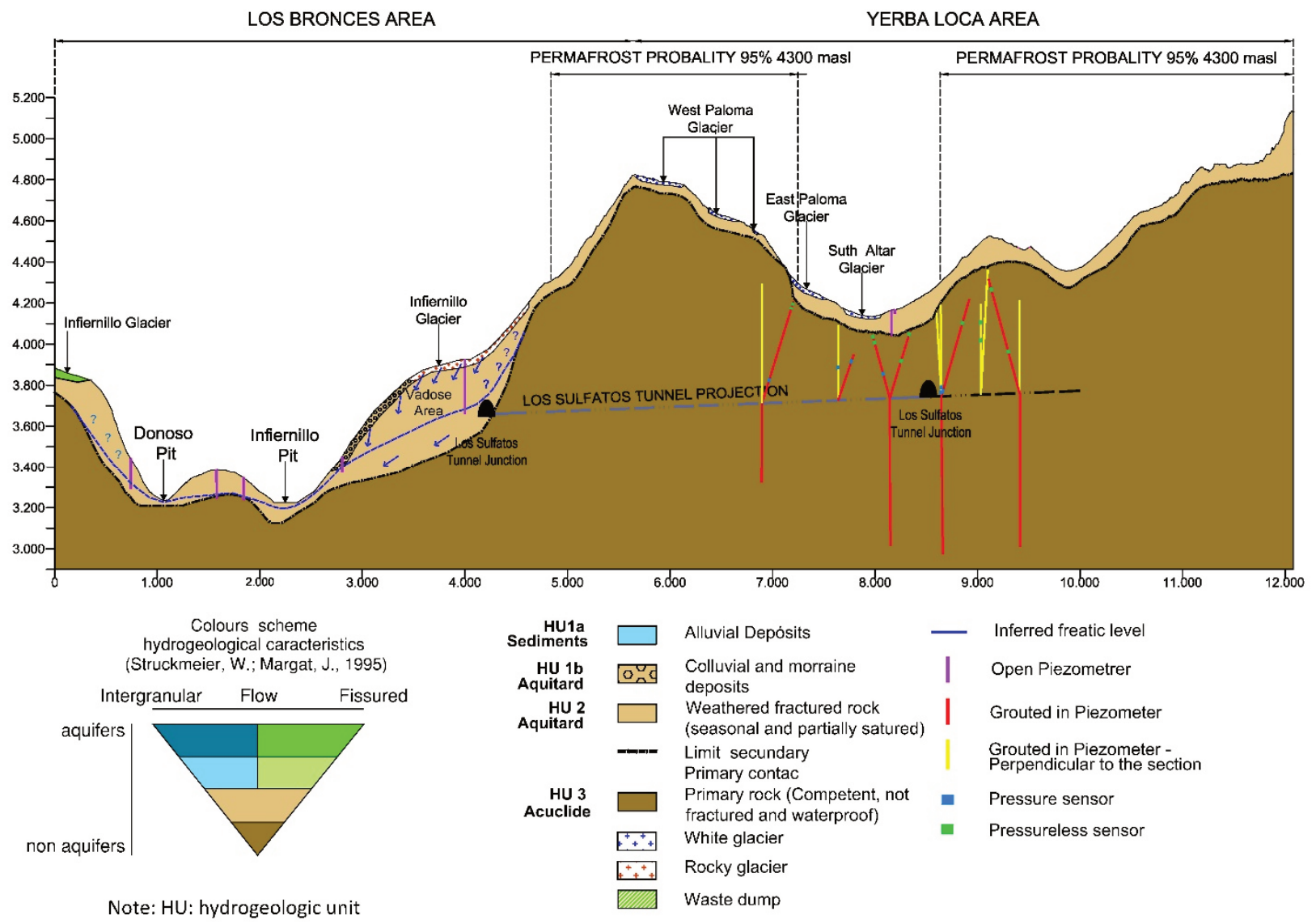

Figure 2 Hydrogeological cross-section, Los Bronces mine district (Anglo American 2019)

Los Bronces Area

HU-1

HU-2

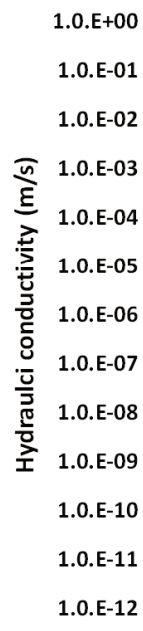

Yerba Loca Area
HU-1
HU-3
HU-3

Legend

Max.

P80

P50

P20

Mín.

Very low

hydraulic

conductivity

(Los Sulfatos

Cu deposit)

HU: Hydrogeological Unit

HU-2 Fractured secondary rock

HU-1: Alluvial, morraine deposits

HU-3 Competent primary rock

Figure 3 Hydrogeological units hydraulic conductivity, Los Bronces mining district (Anglo American 2019) 
The level of detail within the conceptual model must be commensurate with both the available data and the objectives and risks related to the study or mine development stage. The model must identify uncertainties for the hydrogeology and for the engineering designs. Table 1 provides a screening-level checklist example of key components.

Table 1 Example conceptual model screening checklist

\begin{tabular}{|c|c|c|c|}
\hline \multirow[t]{2}{*}{ Conceptual model component } & \multicolumn{3}{|c|}{ Adequacy rating } \\
\hline & Compliant & Partial & Deficient \\
\hline District-scale geology & & $x$ & \\
\hline Ore deposit geology & $x$ & & \\
\hline Major structures & & $x$ & \\
\hline Natural groundwater recharge & & & $x$ \\
\hline Artificial recharge & & $x$ & \\
\hline Groundwater discharge & & $\mathrm{x}$ & \\
\hline Hydraulic properties - ore deposit & & & $x$ \\
\hline Hydraulic properties - district hydrogeologic units & & & $x$ \\
\hline Groundwater gradients - mine scale & & & $x$ \\
\hline
\end{tabular}

\subsection{Preparation of the mine dewatering strategy}

The overall strategy can usually be developed at the conceptual model stage. Key factors will be:

- The magnitude of groundwater control that will be required.

- Whether any of the slope sectors may require enhanced depressurisation.

- The magnitude and scale of required surface water control.

- How the water pumped from the mine will be integrated with the site-wide water balance.

- Mine plan and dewatering program interactions.

Dewatering rates often need to increase when rapid deepening and mine expansion are taking place. Mines with high dewatering rates have the potential to create regional-scale drawdown which may, in turn, increase the level of uncertainties because of the difficulty in characterising a larger area. Many of the mine sites that require large dewatering rates are located in areas of lower-lying topography or areas of high rainfall.

\subsection{Trade-off study for dewatering options}

Selection of the preferred dewatering strategy typically requires a detailed trade-off and engineering study to provide the correct focus. Potential short-term options need to be defined at the conceptual model stage and may include:

- In-pit and ex-pit wells.

- Passive drain holes (horizontal, vertical, inclined).

- Seepage collection systems.

- Recharge interception.

- Water collection ditches and sumps.

- Main sumps in the lower pit. 
The need to implement long-term strategies is typically due to: (i) the hydrogeological setting and the scale of the mine plan and dewatering program, (ii) the need to ensure depressurisation of the pit slopes, (iii) the need to minimise in-pit infrastructure and (iv) high cost during LoA and need for optimisation.

The long-term strategies will typically have a considerable lead time, will involve detailed planning, and usually have a significantly higher capital cost than conventional dewatering systems. They may include:

- Dewatering tunnels or drainage galleries for high volume dewatering flows.

- Tunnels to provide access behind the slope for drain hole drilling to achieve slope depressurisation.

- Directional well drilling to allow the collar to be located outside of the immediate area of mining.

- Deeper, small diameter drilling (vertical or inclined wells) for high performance slim-line pumps.

The type of strategy required will depend on the conceptual model, mine plan and whether the main focus is dewatering or slope depressurisation. The strategy will usually require a combination of options, potentially at different stages of the mining cycle. Dewatering strategy development will involve an initial review completed by a corporate or expert group. An example of the trade-off process is provided in Table 2 .

Table 2 Example trade-off study

\begin{tabular}{|c|c|c|c|c|c|c|c|c|c|}
\hline \multirow{3}{*}{$\begin{array}{l}\text { Alternative } \\
\text { approach }\end{array}$} & \multirow{3}{*}{$\begin{array}{l}\text { LoM } \\
\text { CAPEX } \\
\text { USD } \\
\text { (M) }\end{array}$} & \multicolumn{5}{|c|}{ Economic purposes } & \multicolumn{3}{|c|}{ Risks } \\
\hline & & $\begin{array}{l}\text { Slope } \\
\text { optimisation: } \\
\text { steepening } \\
\text { of better } \\
\text { Factor of } \\
\text { Safety }\end{array}$ & $\begin{array}{l}\text { Supports } \\
\text { mine } \\
\text { operating } \\
\text { efficiency }\end{array}$ & $\begin{array}{l}\text { In-pit } \\
\text { dewatering } \\
\text { infrastructure } \\
\text { reduction }\end{array}$ & $\begin{array}{l}\text { Flow rate } \\
\text { minimisation }\end{array}$ & $\begin{array}{l}\text { Regional } \\
\text { impacts } \\
\text { reduction }\end{array}$ & $\begin{array}{l}\text { Interference } \\
\text { with mining } \\
\text { operations }\end{array}$ & $\begin{array}{l}\text { Mine } \\
\text { operation } \\
\text { cost } \\
\text { escalation }\end{array}$ & $\begin{array}{l}\text { Slope } \\
\text { flattening } \\
\text { or } \\
\text { unplanned } \\
\text { major } \\
\text { unload }\end{array}$ \\
\hline & & USD (M) & USD (M) & USD (M) & USD (M) & USD (M) & USD (M) & USD (M) & USD (M) \\
\hline $\begin{array}{l}1 \text { Sump } \\
\text { pumping }\end{array}$ & $25-40$ & & & & & 100 & 20 & 100 & 1,000 \\
\hline $\begin{array}{l}2 \text { Standard } \\
\text { wells }\end{array}$ & $\begin{array}{l}120- \\
150\end{array}$ & & 100 & & & & 20 & 50 & 700 \\
\hline $\begin{array}{l}3 \text { High } \\
\text { performance } \\
\text { wells }\end{array}$ & $60-80$ & & 150 & 60 & 15 & & & & 600 \\
\hline $\begin{array}{l}\text { 4B Drainage } \\
\text { tunnel }\end{array}$ & $\begin{array}{l}100- \\
150\end{array}$ & 1,000 & 200 & 40 & 30 & 10 & & & \\
\hline
\end{tabular}

\section{$5 \quad$ Step 4: System design}

\subsection{Objectives and prediction of the groundwater and surface water inflow rates}

A good understanding of the water control requirements and the likely inflow rates must first be established from the conceptual model, prior to attempting any analytical or numerical modelling. Prior to determining the type of analysis required, the objectives must first be clearly defined. Objectives may include:

- To support licensing and permitting.

- To better understand the future groundwater dewatering rate and investigate 'what if' scenarios.

- To assess the magnitude and frequency of surface water runoff events that may reach the mine.

- To evaluate dewatering flow effects within the site-wide water balance.

- To evaluate pit slope pore pressures and depressurisation requirements, and to provide estimates for the geotechnical model. 
Frequently, a different type of analysis is required for each of these objectives. It would be unusual that one analytical or numerical model could fulfil all requirements. There are three basic approaches that may be used to predict the groundwater inflow rate: i) water balance approach, ii) analytical model and iii) numerical model. An analytical model may be much quicker to prepare and may offer more flexibility because it can be rapidly updated and calibrated to recent data and empirical responses. It may also be easier to interpret than a numerical model. Whichever approach is used to predict dewatering rates, a 'reality check' on the dewatering predictions is essential, using benchmark experience gained at as many proxy sites as possible.

Estimating surface water inflows can potentially be more straightforward than groundwater. However, the analysis can be complicated by the fact that, in many regions, the period of climatological record is too short to correctly represent the variability of the rainfall so there can be large uncertainty in the prediction of extreme events. This uncertainty may need to be factored into the planning and design process with an appropriate level of contingency for the surface water designs. Figure 4 presents an example of dewatering needs and initial plan at Mogalakwena mine, northern pit (Piteau Associates 2019).

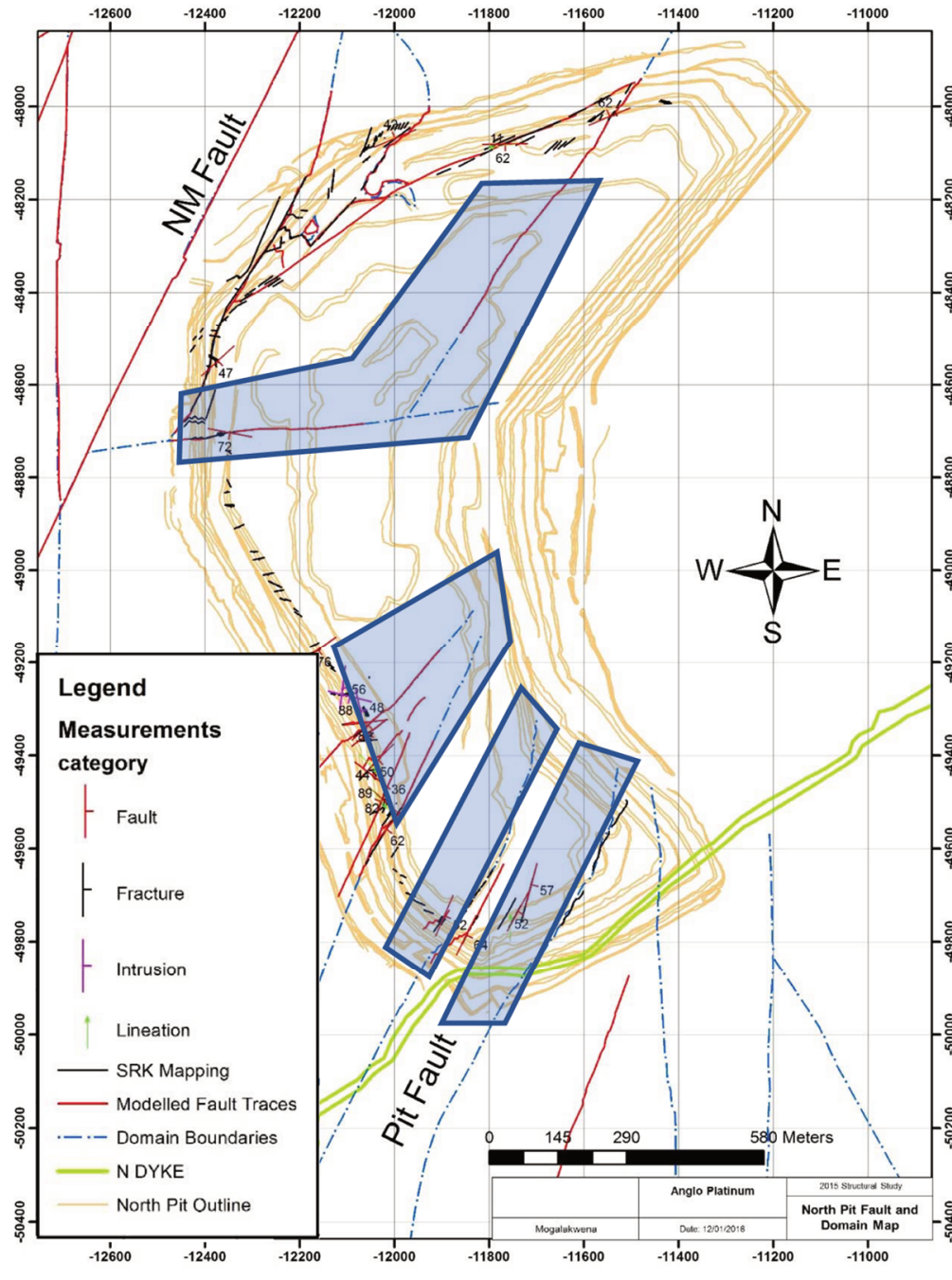

(a)

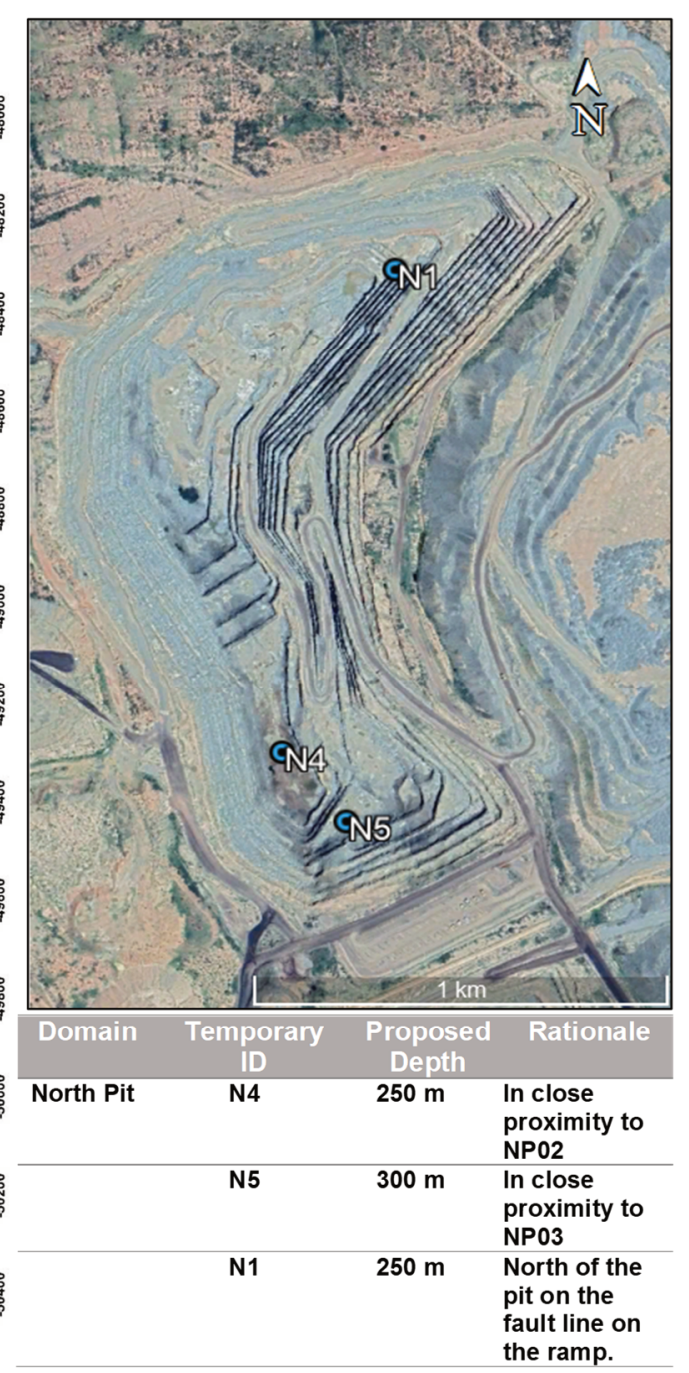

(b)

Figure 4 Mogalakwena North Pit showing sectors where (a) dewatering is required; and (b) locations of proposed in-pit dewatering boreholes

\subsection{Slope depressurisation}

Most open pits require some form of enhanced depressurisation, regardless of the dewatering rate (Beale \& Read 2013). The rate of depressurisation in a pit slope is governed by the balance between recharge and 
discharge, and the ability of the fracture network to transmit water to the discharge points. If recharge enters the slope faster than the rate it can be removed, depressurisation will not be possible. Wherever it is practicable, the interception of recharge before it reaches the mine area is often the most effective method of pore pressure control. Porewater pressure requirements guiding system design are defined by geotechnical stability analysis. System design to control identified risk zones consider previous steps 1 to 3 and focus on recharge interception and/or induced discharge, targeting rock mass or structure sensitive to porewater pressure and taking into consideration passive drainage.

Passive drainage occurs throughout the fracture network when numerous natural flow pathways exist. Active depressurisation is often related to zones of low permeability, such as clay alteration, or zones of very low fracture permeability, where there may be a significant lag in the drainage time compared to other more permeable units.

System design considers recharge interception, using method like contour channels and bench-scale runoff interception. Discharge considers point sources of discharge (i.e. wells and drains) that intersect only a localised part of the fracture network and a relatively small number of permeable flow pathways or drainage galleries for more specific slope-scale depressurisation requirements in low permeability. Figure 5 presents an active versus passive depressurisation example.
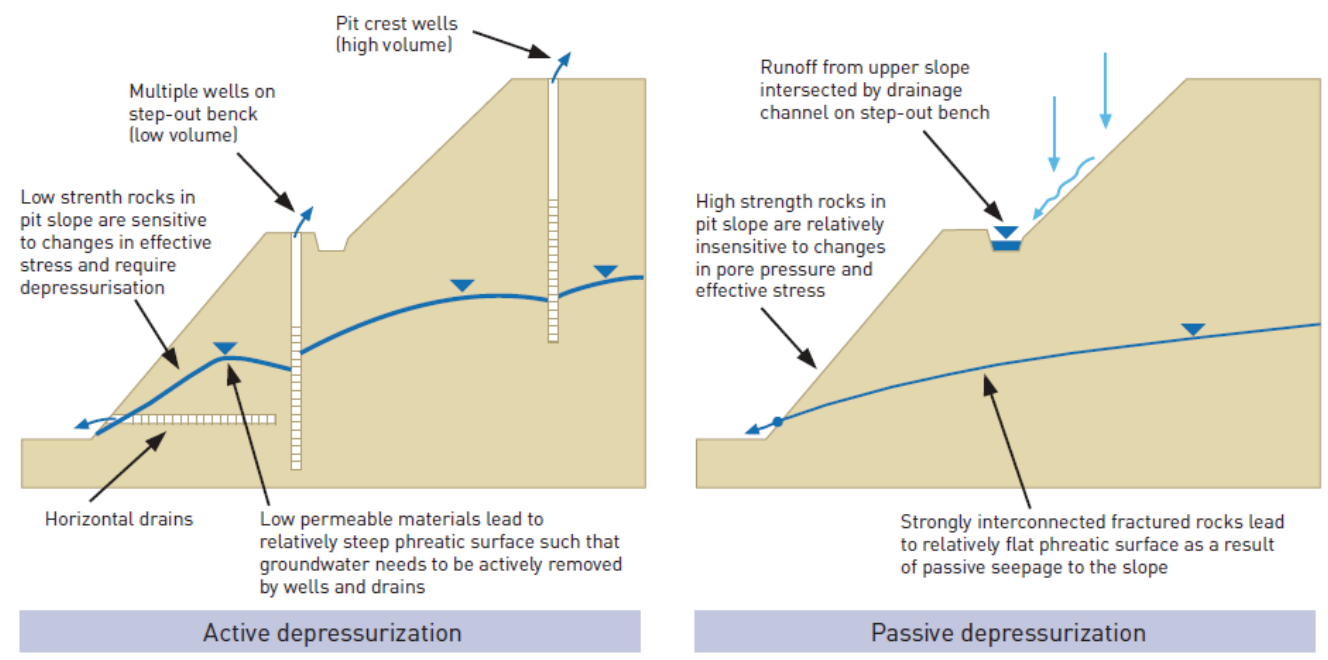

Figure 5 Illustration of active depressurisation and passive depressurisation (after Beale \& Read 2013)

\subsection{Risk assessment}

Water may cause significant risks to the mining operation, enhancing the importance of a robust and fit for purpose system design. Although water risks are unique to each mine, the most common risks associated with the dewatering program and considerations for system design are typically:

- Inaccurate prediction of the dewatering rate: dewatering requirements or slope depressurisation needs, leading to system under-design capacity, delays, no capacity in achieving targets and cost over-runs, requiring systems with flexibility to rapidly increase discharge rate.

- Failure to achieve timely dewatering: potentially leading to a disruption in the ore delivery schedule, or meeting mine plan as per design, requiring systems that enable rapid upscale of capacity.

- Failure to achieve slope depressurisation targets: leading to a reduction in the Factor of Safety for the slope design, and potential instability of the slope, requiring systems able to timely enhance discharge intervention intensity. 
- Errors in the mine water balance: meaning that either: (i) there is insufficient or unreliable water supply, or (ii) unplanned discharge of water offsite becomes necessary, requiring systems integrated to site-wide water balance and regular site-wide reviews.

- The predicted pumped water quality is different to predictions: leading to increased downstream costs, water treatment requirements or external non-compliance with licensing and standards, requiring systems considering contingencies for discharge management.

Basis of design of system designs rely on a robust step 3 conceptual model, based on a suitable step 2 characterisation.

\section{Step 5: Implementation}

\subsection{General mine dewatering and slope depressurisation targets}

For general mine dewatering, the development of a water level target is based on the mine plan. The targets are usually based on lowering the water table below the lowest part of the main pit floor (or below the pit floor in a given sector) ahead of the mine excavation and are often specified on a six monthly or annual basis.

Typically, the dewatering target is specified for lowering the water table a given distance below the advancing pit floor by a given date; for example, $20 \mathrm{~m}$ below the pit floor by year-end or $30 \mathrm{~m}$ (two benches) at mine phases with rapid deepening rates. However, in some instances, to provide adequate time to achieve the required drainage for lower permeability units, the dewatering target may be specified to lower the water table to a certain elevation by a given time (say 12 months) ahead of the mine plan.

Pore pressure targets can sometimes be set based on achieving a simple phreatic level by a given point in time. However, it is more often prudent to provide purpose-placed piezometers on each key geotechnical design section, and to specify the targets based on achieving given head values in some or all the piezometers by a given time (often annually). Performance monitoring using the piezometer arrays is essential to ensure that the program stays on track.

\subsection{Integration with mine planning}

A key consideration for the design and implementation of the dewatering system is the space available in-pit to install the water control measures. This requires integration with mine planning and with the geotechnical program at different stages of planning, considering the following issues:

- Provision of working areas within the mine plan for the drilling and installation of any wells and drain holes, given the likely heavy vehicle production traffic.

- Sequencing of the installation of the wells and drain holes with the active mine operations.

- Safety concerns due to rockfall or overspill above the drilling sites.

- Provision of sufficient lead time for the installed system to achieve the desired level of depressurisation.

- Provision of ongoing access for maintenance of both the installations themselves and any associated ancillary equipment such as pumps, reticulation pipelines or drainage ditches.

- Location of the installations so they will survive for the required period of time, considering the ongoing mining operation and the timing of future mine expansions and slope push-backs.

- Design of the slope depressurisation measures with sufficient flexibility to accommodate changes to the mine plan.

It is often possible to provide the required in-pit access by advance planning and sequencing the drainage measures, or sometimes by making minor adjustments to the mine plan. Operational considerations are useful when planning the location of in-pit drainage measures; for example, Figure 6 presents installation of 
drainage measures on catch benches close to the point where the benches intersect the haul ramps. In the case of Los Bronces mine, the very abrupt topography limits out-pit pumping wells and a dedicated dewatering bench was incorporated into the design of the Infiernillo 7A mining phase (Figure 7).

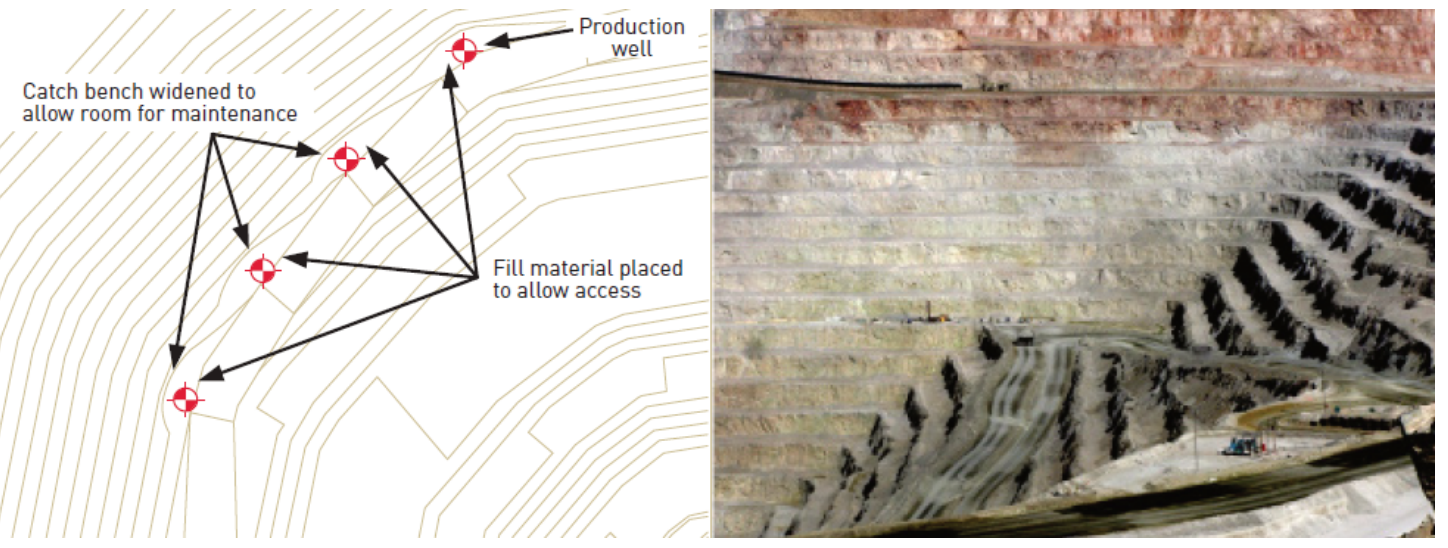

Figure 6 Illustration of in-pit drilling access (after Beale \& Read 2013)

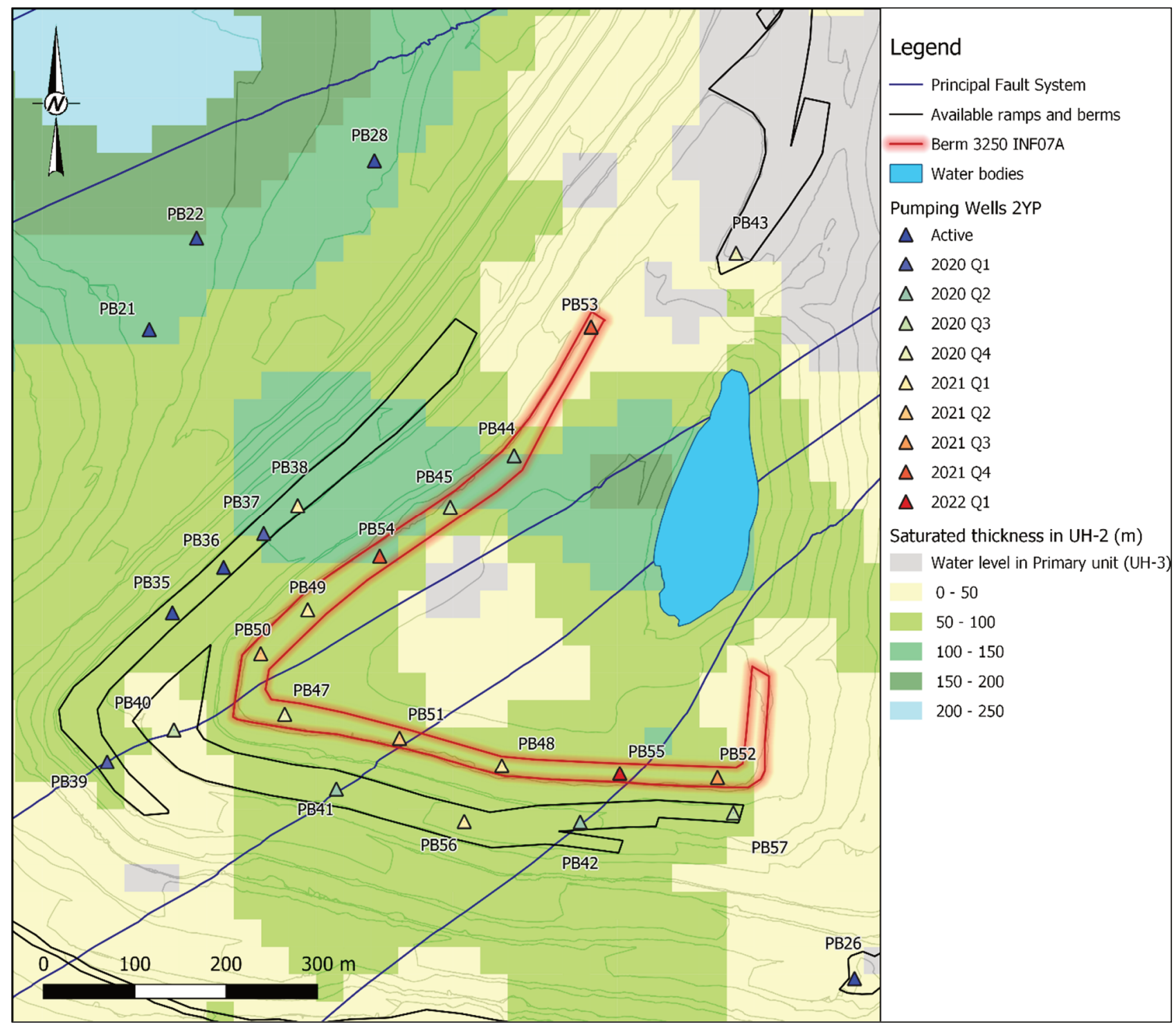

Figure 7 Los Bronces mine, dedicated dewatering bench for Infiernillo 7A mining phase 


\section{$7 \quad$ Step 6: monitoring and reporting}

Verification of the actual performance is a key component of the mining cycle. Some level of uncertainty in the dewatering system is inevitable. Therefore, it is essential that the monitoring results are used to interactively adjust the dewatering system design and implementation. For each defined reporting period, changes to the mine plan and the results of the monitoring program must be evaluated. The implementation of the dewatering program must be adjusted accordingly. Reporting process based on LOP guidelines (Beale \& Read 2013) is summarised in Table 3, and Figure 8 provides an example of the Los Bronces monthly dewatering dashboard focussed on system response based on piezometer data and pumping wells operational performance.

Table 3 Typical reporting process (after Beale \& Read 2013)

\begin{tabular}{|c|c|c|}
\hline Daily operations meetings & $\begin{array}{l}\text { Report on current daily dewatering } \\
\text { activities }\end{array}$ & $\begin{array}{l}\text { Attended by mine engineering, } \\
\text { operations and maintenance } \\
\text { staff }\end{array}$ \\
\hline Weekly dewatering meeting & $\begin{array}{l}\text { Review of key monitoring results and } \\
\text { comparison to the defined targets; } \\
\text { adjustments to the detailed (day-to- } \\
\text { day) program }\end{array}$ & $\begin{array}{l}\text { Attended by mine engineering, } \\
\text { operations and maintenance } \\
\text { staff, and senior mine } \\
\text { management }\end{array}$ \\
\hline Monthly progress report & $\begin{array}{l}\text { Progress towards the required } \\
\text { targets and recommend } \\
\text { modifications to the detailed short- } \\
\text { term action and mitigation plan (3-6 } \\
\text { months) }\end{array}$ & $\begin{array}{l}\text { Distributer to mine engineering, } \\
\text { operations and maintenance } \\
\text { staff, senior mine management, } \\
\text { corporate staff, external advisors }\end{array}$ \\
\hline $\begin{array}{l}\text { Quarterly factual data } \\
\text { update }\end{array}$ & Standardised analysis and reporting & $\begin{array}{l}\text { Distributed to engineering staff, } \\
\text { mine management, corporate } \\
\text { staff and external advisors }\end{array}$ \\
\hline $\begin{array}{l}\text { Six monthly or annual } \\
\text { strategy review meeting }\end{array}$ & $\begin{array}{l}\text { Review of the dewatering system and } \\
\text { results by mine staff, stakeholders } \\
\text { and external experts. The goal is to } \\
\text { confirm that targets are being } \\
\text { achieved and/or to evaluate the } \\
\text { reasons and consequences of not } \\
\text { achieving the targets }\end{array}$ & $\begin{array}{l}\text { Attended by engineering staff, } \\
\text { mine management, corporate } \\
\text { staff and external advisors }\end{array}$ \\
\hline
\end{tabular}




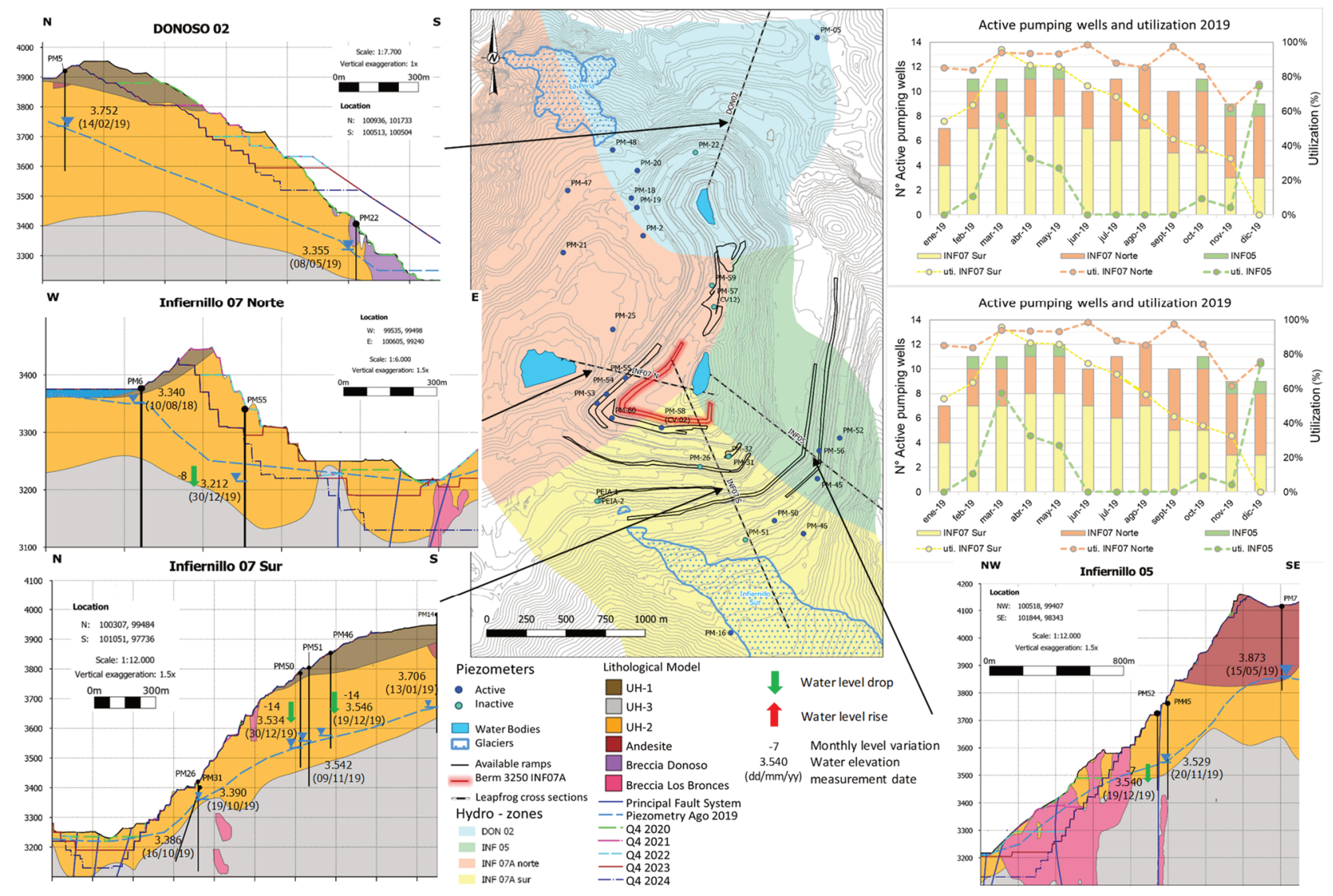

Figure 8 Los Bronces monthly dewatering dashboard example (after Golder 2019)

\section{Acknowledgement}

The authors thanks Mogalakwena and Los Bronces mines for the support provided at site visits and relevant information during the development of the strategic dewatering plan framework.

\section{References}

Anglo American \& Piteau Associates 2018, Strategic Dewatering Plan Framework, Development and Implementation, internal document.

Anglo American 2019, Estudio de Impacto Ambiental, Proyecto Los Bronces Integrado (Environmental Impact studio, Los Bronces Project Integrated), internal document.

Beale, G \& Read, J 2013, Guidelines for Evaluating Water in Pit Slope Stability, CSIRO Publishing, Clayton.

Golder 2019, Los Bronces Dewatering Support, Monthly Dashboard Development, internal document.

Piteau Associates 2019, Mogalakwena Strategic Dewatering Plan, Development and Implementation, internal document.

Struckmeier, F \& Margat, J 1995, 'Hydrogeological maps, a guideline and a standard legend', International Contributions to Hydrogeology, vol 17. 
